\title{
ОЦІККА ЗНАНЬ СТУДЕНТІВ-ВИПУСКНИКІВ ЗА РЕЗУЛЬТАТАМИ ДЕРЖАВНОГО ІСПИТУ 2012/2013 НАВЧАЛЬНОГО РОКУ
}

\author{
К. М. Амосова, Г. В. Мостбауер, С. Ю. Калініна, І. В. Кричинська \\ Національний медичний університет імені О. О. Богомольия
}

\section{ASSESSMENT OF GRADUATE STUDENTS KNOWLEDGE FOR THE STATE EXAM RESULTS 2012/2013 SCHOOL YEAR}

\author{
K. M.Amosova, H. V. Mostbauer, S. Yu. Kalinina, I. B. Krychynska \\ National Medical University by O. O. Bohomolets
}

\begin{abstract}
У статті проаналізовано успішність студентів-випускників медичного факультету № 2 Національного медичного університету імені О. О. Богомольця за 2012/2013 навчальний рік.

The article analyzes the success of graduate students of medical faculty № 2 National Medical University by O. O. Bohomolets by 2012/2013 school year.
\end{abstract}

Вступ. Основним критерієм ефективності навчального процесу є засвоєння студентом базисних знань та спроможність до реального їх приросту, а також формування навичок професійно-орієнтованої діяльності. Фактично набуваються компетенції, котрі формують нову модель фахівця, який після завершення процесу навчання здатний самостійно орієнтуватися в клінічних ситуаціях і бачити шляхи їх раціонального вирішення.

Обов'язковою складовою процесу навчання та інструментом оцінювання його результатів є державний іспит. Його оцінка є результуючою всього процесу навчання.

Кафедра внутрішньої медицини № 2 Національного медичного університету імені О. О. Богомольця більше 10 років проводить всебічний аналіз результатів різних форм контролю знань випускників медичного факультету № 2 .

Метою даної роботи був аналіз успішності студентіввипускників за допомогою основних засобів контролю: рейтингового бала, результатів за державний іспит та ліцензійного інтегрованого іспиту “Крок-2”.

Основна частина. У роботі представлені результати успішності 297 студентів 6 курсу (вітчизняні та іноземні студенти) медичного факультету № 2 за 2012/ 2013 навчальний рік. Аналізувалися індивідуальні показники успішності за весь період навчання на кафедрі (оцінка за 4 модулі), результати практично-орієнтова- ного державного іспиту (всіх його складових: оцінювання роботи студента безпосередньо біля ліжка хворого, демонстрації основних умінь і практичних навичок згідно з ОКХ спеціаліста за спеціальністю "Лікувальна справа" з використанням фантомів, муляжів, навчальних наочних матеріалів, вирішення ситуаційних задач) та результати ліцензійного інтегрованого іспиту “Крок-2" у відсотках правильних відповідей. Проведений кореляційний аналіз між усіма складовими та оцінена достовірність виявлених зв'язків.

Серед вітчизняних студентів аналіз показав наявність стійкого, середнього ступеня сили зв' язку між рейтинговою оцінкою і результатами державного іспиту $(r=0,69, p<0,001)$. Цей зв'язок був слабшим $з$ результатом іспиту “Крок-2" $(\Gamma=0,62, \mathrm{p}<0,01)$ та найменшим між державним іспитом та “Крок-2” ( $\Gamma=0,52$, $\mathrm{p}<0,01)$. Серед іноземних студентів наявна високої сили кореляція $\Gamma=0,84, \mathrm{p}<0,01 ; \Gamma=0,78, \mathrm{p}<0,01 ; \Gamma=0,85$, p <0,01 у відповідних позиціях. Необхідно зазначити, що більшою чи меншою мірою направленість результатів зберігається протягом 5 років.

Висновок. Отримані результати свідчать про те, що освітня програма студентів медичних вузів протягом усього періоду навчання відповідає вимогам сучасної медицини, а форми ії контролює достатньо об'єктивними. У цілому це дозволяє підготувати випускника з достатньою теоретичною та практичною підготовкою. 